\title{
Using Conceptests to Assess and Improve Student Conceptual Understanding in Introductory Geoscience Courses
}

\author{
David A. McConnell \\ David N. Steer \\ Katharine D.Owens \\ Jeffrey R. Knott \\ Stephen Van Horn \\ Walter Borowski \\ Jeffrey Dick \\ Annabelle Foos \\ Michelle Malone \\ Heidi McGrew \\ Lisa Greer \\ Peter J. Heaney
}

\author{
Department of Geology, University of Akron, Akron, OH 44325-4101, \\ dam6@uakron.edu \\ Department of Geology, University of Akron, Akron, OH 44325-4101 \\ Department of Curricular and Instructional Studies, University of Akron, Akron, \\ $\mathrm{OH}$ 44325-4205
}

Department of Geological Sciences, California State University, Fullerton, P.O. Box 6850, Fullerton, CA 92834

Department of Geology, Muskingum College, 163 Stormont Street, New Concord, $\mathrm{OH} 43762$

Department of Earth Sciences, Eastern Kentucky University, 521 Lancaster Avenue, Richmond, KY 40475

Department of Geological and Environmental Sciences, Youngstown State University, Youngstown, OH 44555

Department of Geology, University of Akron, Akron, OH 44325

Department of Geology, Western Washington University, 516 High Street, Bellingham, WA 98225-9080

Department of Geology, University of Dayton, Dayton, OH 45469-2364

Washington and Lee University, Geology Department, Lexington, VA 24450

Pennsylvania State University, Department of Geosciences, University Park, PA 16802

\section{ABSTRACT}

Conceptests are higher-order multiple-choice questions that focus on one key concept of an instructor's major learning goals for a lesson. When coupled with student interaction through peer instruction, conceptests represent a rapid method of formative assessment of student understanding, require minimal changes to the instructional environment and introduce many of the recognized principles of effective teaching that enhance student learning. In this study, instructors from several different institutions developed over 300 conceptests for the geosciences. These instructors then used this suite of concept questions in a wide range of classroom settings, including large introductory general education Earth Science courses for non-majors at open enrollment institutions, smaller physical geology classes suitable for majors at private colleges, and in introductory geology laboratory settings. Results of pre- and post-class Geoscience Concept Inventory (GCI) testing and qualitative feedback from students and instructors showed that conceptests increased attendance, improved student satisfaction, and enhanced student achievement. Participating instructors found implementation of conceptests into their classes straightforward and required less than 30 minutes of preparation per class. The conceptest question database is available on-line for geoscience instructors.

\section{INTRODUCTION}

There is widespread recognition among many practicing scientists that student engagement in the sciences must be improved if we are to ensure a continued supply of able scientists and a scientifically literate society
(American Geophysical Union, 1994; National Science Foundation, 1996; National Research Council, 1997; National Science Board, 2002, 2003; Handelsman et al., 2004). National surveys of incoming freshmen reveal that approximately $25-30 \%$ initially intend to major in science, technology, engineering and mathematics (STEM) fields (National Science Board, 2002) but several researchers report that approximately $40-50 \%$ of STEM majors transfer into non-STEM programs during their college experience (e.g., Astin and Astin, 1993; Strenta et al., 1994). Seymour and Hewitt (1997) noted that $83 \%$ of students in STEM disciplines expressed concern about poor teaching specifically mentioning, dull courses, disengaged instructors, and unsupportive teaching strategies (Tobias, 1990; Strenta et al., 1994). They suggested that a thorough revision of teaching and learning in first year STEM courses would likely improve student retention rates (Seymour and Hewitt, 1997). This view was echoed by the National Science Board (2003, p. 20), which stated that greater retention in STEM disciplines

...will require modification of the educational environment, particularly better teaching and advising . . . More institutional resources must be directed to improving the quality of teaching, the nature of introductory classes, the design of facilities to support new teaching methods...

Of the three directions highlighted by the National Science Board, design or redesign of facilities requires long term planning and substantial institutional and financial commitment. Secondly, introductory classes at many institutions are often an integrated prerequisite for many other classes, which limits changes in the nature of the course or curriculum. As a result, improving the quality of teaching remains as the most cost effective, 
tangible, and timely improvement that STEM departments may impose to improve student engagement and retention. Underlying improved teaching is a desire to enhance student comprehension, thereby promoting a scientifically literate society.

However, time spent by STEM instructors improving teaching would likely reduce time available for obtaining grant funding and producing research papers, which has equal or greater value at many institutions.

Peer instruction was developed to provide a mechanism for introducing effective pedagogy into lecture classes without having to make acute changes to course content or organization (Mazur, 1997). Peer instruction introduces the use of conceptual multiple choice questions, conceptests, that are initially analyzed by students working alone, and then in a pair or a small group. This technique and has been effectively used in STEM disciplines such as physics and chemistry (e.g., Mazur, 1997; Kovac, 1999); however, there have been few reports on the use of conceptests in the geosciences (McConnell et al., 2003; Greer and Heaney, 2004) and no attempts to examine the: 1. Integration of peer instruction into the wide variety of geoscience classes; 2. Use of different student response methods; and, 3 . Contrasts among institutions with academically distinct student populations. This paper describes the classroom procedures employed, as well as instructor and student qualitative and quantitative responses to the introduction of peer instruction into introductory geoscience courses. This study utilized several different student response methods to answer conceptests at higher education institutions across the United States representing a variety of student populations. Our data show that instructors easily integrated conceptests into instruction and that their use measurably improved student comprehension, attendance and enthusiasm.

\section{BACKGROUND AND METHODS: CONCEPTESTS AND PEER INSTRUCTION}

The use of conceptests has proved successful in increasing student engagement and improving student learning in physics (Mazur, 1997; Sokoloff and Thornton, 1997; Hake, 1998; Crouch and Mazur, 2001; Jones et al., 2001; Pilzer, 2001; Cox and Junkin, 2002), chemistry (Kovac, 1999; Landis et al., 2001), math (Pilzer, 2001), and physiology (Rao and DiCarlo, 2000). Student satisfaction with courses or instructors using conceptests generally increased (Mazur, 1997; Judson and Sawada, 2002; Meltzer and Manivannan, 2002; McConnell et al., 2003; Greer and Heaney, 2004), but in some cases decreased (Piepmeier, 1998; Jones et al., 2001) or showed mixed results (Crouch and Mazur, 2001). Quantitative data (Judson and Sawada, 2002; McConnell et al., 2003; Greer and Heaney, 2004) and anecdotal reports (Landis et al., 2001) support interpretations that the use of this teaching method, especially when matched with an electronic response system, can lead to significant improvements in student attendance.

The teaching strategies used in the implementation of conceptests and peer instruction mirror the principles of good practice in undergraduate education defined by Chickering and Gamson (1987) and validated by extensive research (Sorcinelli, 1991). The proper execution of conceptests and peer instruction results in the application of the seven principles as follows:

Encourage student-faculty contact - Peer instruction provides faculty with an opportunity to interact with students by facilitating small-group student discussions as $\mathrm{s} /$ he moves around the classroom. These less formal, more conversational, settings can highlight the low inference behaviors such as enthusiasm that students use to differentiate an outstanding teacher from an average one (Murray, 1983).

Encourage cooperation among students - The social construction of knowledge is a common theme in much of the recent research on science education (Macdonald and Korinek, 1995; Bykerk-Kauffman, 1995; Ebert-May et al., 1997; Murck, 1999). Peer instruction provides an occasion for students to talk and listen to their neighbors in formal or informal teams to improve their understanding of critical concepts. This process helps form social bonds essential for the ready exchange of ideas between students in large classes (Wenk et al., 1997).

Encourages active learning - The use of conceptests turns students from passive listeners into active participants who are involved in the construction of their own knowledge. The benefits of active learning methods in general can be seen in improvements in student attitudes about the science (Gibbons, 1994; Ebert-May et al., 1997; Reynolds and Peacock, 1998) and increases in standardized test scores (Mazur, 1997; Hake, 1998; Stokstad, 2001).

Give prompt feedback - Formative assessment during class can measure student understanding immediately following the introduction of key concepts. The use of conceptests and peer instruction compares favorably to other active learning methods as rapid feedback is possible with this technique. This is especially true for instructors using electronic classroom response systems (McConnell et al., 2003; Greer and Heaney, 2004) that can be programmed to display histograms of class responses before and after peer instruction.

Emphasize time on task - Well-crafted conceptests can focus student attention on critical concepts rather than basic facts. As relatively small numbers of conceptests are posed per class, it is straightforward for students to deconstruct the questions to recognize the principal ideas presented in each lecture.

Communicate high expectations - Conceptests can be created to address specific teaching and learning goals that target what students are expected to know and be able to do. The integration of conceptests into lecture sets higher expectations for student performance than simply taking notes and can challenge students to seek understanding of concepts, not just memorization of facts.

Respect diverse talents and ways of learning - A traditional passive lecture environment that is characterized by an instructor presenting information to a group of note-taking students (McManus, 2002) is well suited to auditory learners who prefer to work alone and who will ask questions in class (Bykerk-Kauffman, 1995; Fleming, 1995). Unfortunately such students are a relatively rare species in audiences composed chiefly of freshmen and sophomores who are more likely to learn through visual cues or combinations of reading and writing (Fleming, 1995). Furthermore, students enter these classes at different cognitive stages and need opportunities to grow underdeveloped intellectual skills (McConnell et al., 2005). Peer instruction centered on conceptests teaches some students how to think critically 
a) Examine the map below and answer the question that follows. How many plates are present?

a) $3(26 \% ; 0 \%)$ b) $4(19 \% ; 18 \%)$ c) $5(44 \% ; 75 \%)$ d) $6(11 \% ; 7 \%)$

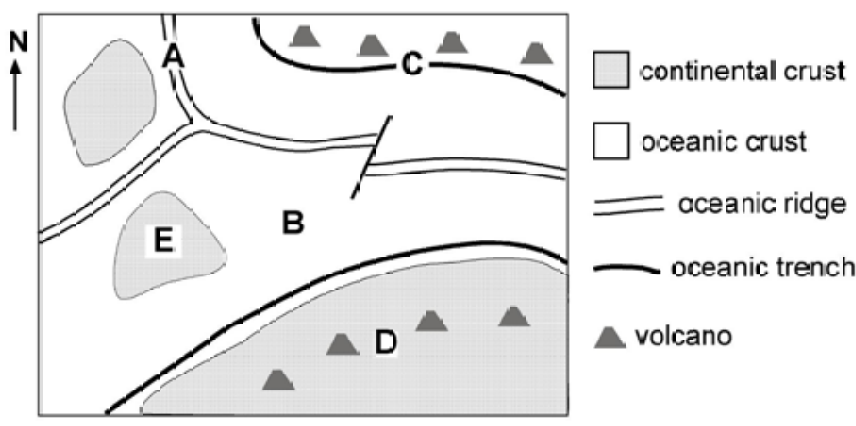

b) A volcano formed over a hot spot in the Pacific Ocean would travel approximately a constant rate of plate motion.)
a) $1-2 \mathrm{~m}(20 \% ; 3 \%)$
b) $100-200 \mathrm{~m}(44 \% ; 66 \%)$
a) $10-20 \mathrm{~km}(28 \% ; 28 \%)$
d) $1000-1500 \mathrm{~km}(8 \% ; 3 \%)$

c) Which of the following mineral formulas represents an oxide?
a) $\mathrm{FeS}_{2}(6 \% ; 3)$
c) $\mathrm{Fe}_{2} \mathrm{O}_{3}(56 \% ; 83 \%)$
b) $\mathrm{KAlSi}_{3} \mathrm{O}_{8}(9 \% ; 3 \%)$
c) $\mathrm{CaSO}_{4} 2 \mathrm{H}_{2} \mathrm{O}(28 \% ; 10 \%)$

d) A and B represent locations on two separate plates. The curved black line represents the plate boundary. The arrows show the direction of plate motion and the rates of motion are indicated.

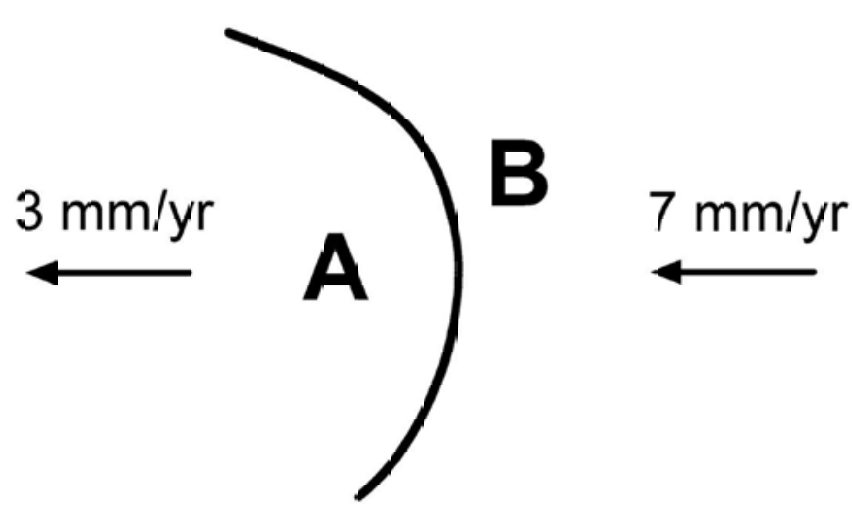

What kind of plate poundary is present between A and B?
a) transform $(14 \% ; 4 \%)$
c) divergent $(21 \% ; 4 \%)$
b) convergent $(32 \% ; 59 \%)$
d) none $(32 \% ; 33 \%)$

Figure 1. Sample conceptests used in introductory classes at the University of Akron (a) or Muskingum College (b, c, d). Proportion of students choosing each answer initially and after peer instruction is indicated for each question. The proportion of correct responses increased by $22-31 \%$ as a result of peer instruction. while others can explore the depth of their understanding by taking on the role of peer instructors.

\section{CONCEPTEST DEVELOPMENT}

Effective conceptests are not simple content-based multiple-choice questions that rely on the student re-reading their lecture notes or memorizing a fact or definition. Instead, conceptests are designed to assess student understanding of the principal concepts underlying the lecture material (Mazur, 1997; Figure 1). Conceptests may be considered as equivalent to comprehension, application or analysis questions as defined by Bloom's Taxonomy (McConnell et al., 2003).

An easily recognized problem with implementing conceptests in the classroom is the lack of available geoscience questions. In July 2003, several instructors from various institutions from across the United States developed over 300 conceptests for the geosciences. Questions were edited and reviewed, often several times, to assure accuracy, level of questioning and clarity. An added benefit of group question development was that by using the same question bank, instructors could provide some certainty that their classroom experiences were similar. These 300 questions formed the initial geoscience conceptests that instructors used the subsequent academic year.

\section{GENERAL CLASSROOM PROCEDURE}

Instructors in our study adhered to the following protocol relatively consistently when using conceptests and peer instruction as formative assessment in their classes.

1. Instructor presented a 10-20 minute lecture.

2. A conceptest was then posted on the chalkboard or screen. Students considered the question individually for a short time (30 seconds to 1 minute) and chose an answer.

3. Students indicated their answers using a variety of methods. In the simplest case students raised their hands as choices were presented by the instructor (Kovac, 1999; Landis et al., 2001). Alternatively students held large colored or lettered answer cards (Uno, 1996; Mazur, 1997; Jones et al., 2001; Meltzer and Manivannan, 2002) or wrote answers on answer sheets (Piepmeier,1998; Rao and DiCarlo, 2000), or used an electronic classroom communication system or computer software (Wenk et al., 1997; Crouch and Mazur, 2001; Cox and Junkin, 2002; McConnell et al., 2003; Greer and Heany, 2004). Some electronic systems allowed students to declare their level of confidence in their choice.

4. The instructor then evaluated student responses. The optimal range of correct student responses is $35-70 \%$ (Crouch and Mazur, 2001). If fewer than 35\% of the responses are correct, students do not understand the topic well enough to discuss the subject or the question is unclear or too difficult. In such cases, instructors may have students offer interpretations of what the question is asking and what information they would need to provide an answer. Such discussions may reveal inconsistencies with the question or gaps in student understanding. If more than $70 \%$ of the class answered correctly in their first response, the question was probably too 


\begin{tabular}{|c|c|c|c|c|c|c|}
\hline Institution & Course & Class Size & $C Q$ per Class & PI Group Size & $\begin{array}{c}\text { Response to } \\
\text { CQ }\end{array}$ & Assessment \\
\hline $\begin{array}{c}\text { California State } \\
\text { University, } \\
\text { Fullerton }\end{array}$ & $\begin{array}{l}\text { Physical } \\
\text { Geology }\end{array}$ & 100 & $1-2$ & $2-4$ & Show of hands & $\begin{array}{c}\text { Pre \& Post } \\
\text { GCI; Instructor } \\
\text { observations. }\end{array}$ \\
\hline $\begin{array}{c}\text { California State } \\
\text { University, } \\
\text { Fullerton }\end{array}$ & $\begin{array}{l}\text { Physical } \\
\text { Geology }\end{array}$ & 40 & 1 & 2 & Show of hands & $\begin{array}{l}\text { Instructor } \\
\text { observations. }\end{array}$ \\
\hline $\begin{array}{l}\text { Muskingum } \\
\text { College }\end{array}$ & $\begin{array}{l}\text { Introduction to } \\
\text { Geology \& } \\
\text { Environmental } \\
\text { Geology }\end{array}$ & 90 & $1-3$ & $2-4$ & $\begin{array}{l}\text { Electronic } \\
\text { response } \\
\text { system }\end{array}$ & $\begin{array}{l}\text { Pre \& Post } \\
\text { GCI; Student } \\
\text { survey; } \\
\text { Instructor } \\
\text { observations. }\end{array}$ \\
\hline $\begin{array}{c}\text { Pennsylvania } \\
\text { State } \\
\text { University }\end{array}$ & Planet Earth & 140 & $2-3$ & $2-4$ & $\begin{array}{l}\text { Electronic } \\
\text { response } \\
\text { system }\end{array}$ & $\begin{array}{c}\text { Student } \\
\text { survey; } \\
\text { Instructor } \\
\text { observations. }\end{array}$ \\
\hline $\begin{array}{l}\text { University of } \\
\text { Akron }\end{array}$ & Earth Science & 160 & $2-4$ & 4 & $\begin{array}{l}\text { Electronic } \\
\text { response } \\
\text { system }\end{array}$ & $\begin{array}{l}\text { Pre \& Post } \\
\text { GCI; Student } \\
\text { interviews. }\end{array}$ \\
\hline $\begin{array}{c}\text { University of } \\
\text { Dayton }\end{array}$ & $\begin{array}{l}\text { Dynamic } \\
\text { Planet }\end{array}$ & $14-36$ & $0-1$ & $2-4$ & $\begin{array}{l}\text { Show of hands, } \\
\text { or cards }\end{array}$ & $\begin{array}{c}\text { Pre \& Post } \\
\text { GCI; Instructor } \\
\text { observations. }\end{array}$ \\
\hline $\begin{array}{l}\text { Western } \\
\text { Washington } \\
\text { University }\end{array}$ & $\begin{array}{l}\text { Introductory } \\
\text { Geology } \\
\text { Laboratory }\end{array}$ & $24-35$ & 2 & $2-4$ & $\begin{array}{l}\text { Show of hands, } \\
\text { or cards }\end{array}$ & $\begin{array}{c}\text { Student } \\
\text { survey; } \\
\text { Instructor } \\
\text { observations. }\end{array}$ \\
\hline $\begin{array}{l}\text { Washington \& } \\
\text { Lee University }\end{array}$ & $\begin{array}{l}\text { Historical } \\
\text { Geology }\end{array}$ & 22 & $2-3$ & $2-4$ & $\begin{array}{l}\text { Electronic } \\
\text { response } \\
\text { system }\end{array}$ & $\begin{array}{c}\text { Student } \\
\text { survey; } \\
\text { Instructor } \\
\text { observations. }\end{array}$ \\
\hline $\begin{array}{l}\text { Youngstown } \\
\text { State } \\
\text { University }\end{array}$ & $\begin{array}{l}\text { Historical } \\
\text { Geology }\end{array}$ & 20 & $1-2$ & $2-4$ & $\begin{array}{l}\text { Electronic } \\
\text { response } \\
\text { system }\end{array}$ & $\begin{array}{c}\text { Pre GCI; Pre \& } \\
\text { Post } \\
\text { knowledge } \\
\text { survey; } \\
\text { Student } \\
\text { survey; } \\
\text { Instructor } \\
\text { observations. }\end{array}$ \\
\hline
\end{tabular}

Table 1. Integration of conceptests into university introductory geoscience classes. CQ per Class - Number of conceptests used per class; PI Group Size - Number of students involved in peer instruction groups; Response to CQ - Method students used to indicate their answer choices; GCI - Geosciences Concepts Inventory (Libarkin and Anderson, 2005).

easy. Additional discussion will not yield much improvement in student answers. Instructors may employ the strategy of explaining the answer and 8 moving forward with lecture. When correct responses are between $35-70 \%$, students were instructed to discuss the reasons for their choices with their neighbors (peer instruction) in pairs or small groups for 1-2 minutes (Mazur, 1997).

5. Lastly, the class was polled again. At this point, instructors either selected group spokespersons to provide a brief explanation of the correct answer or the instructor summarized the response for the class.

\section{RESULTS}

Integration of Conceptests and Peer Instruction into Geoscience Classes - Conceptests were used for a range of class settings from large (>100 students) lecture courses to small population (14 students) laboratory sections (Table 1). All classes were taught as part of the home institution's general education curriculum and thus mainly served freshmen but often included upper class students. The institutions ranged from large $(>25,000$ students) open enrollment public universities to small $(<5,000$ students), private institutions (Table 1$)$. On average, instructors posed two conceptests per class and students worked with peers in small, generally informal, groups of 2-4 students each (Table 1 ).

Instructors at seven of the participating institutions had access to the 300-question conceptest database. Washington \& Lee and Pennsylvania State universities employed questions devised elsewhere (Greer and Heaney, 2004). The proportion of student first-time correct responses to the questions was consistently in the range of 35-70\%, as recommended by Mazur (1997), for the majority of questions drawn from the database ( Figure 1a, b, c) but occasionally initial responses fell outside this range (Figure 1d). For example, 95\% of conceptests used in classes at Muskingum College had response rates in the optimal range. The proportion of post-discussion responses almost always increased, typically by $20-30 \%$ (Figure 1 ).

Instructors used conceptests for summative assessment as well. For example, at California State University Fullerton, conceptests were used to convert pre-exam review sessions from relatively unfocused discussions of course content to a careful analysis of concepts that students identified as challenging. Graduate assistants managing laboratory classes at Western Washington University used two conceptests at 


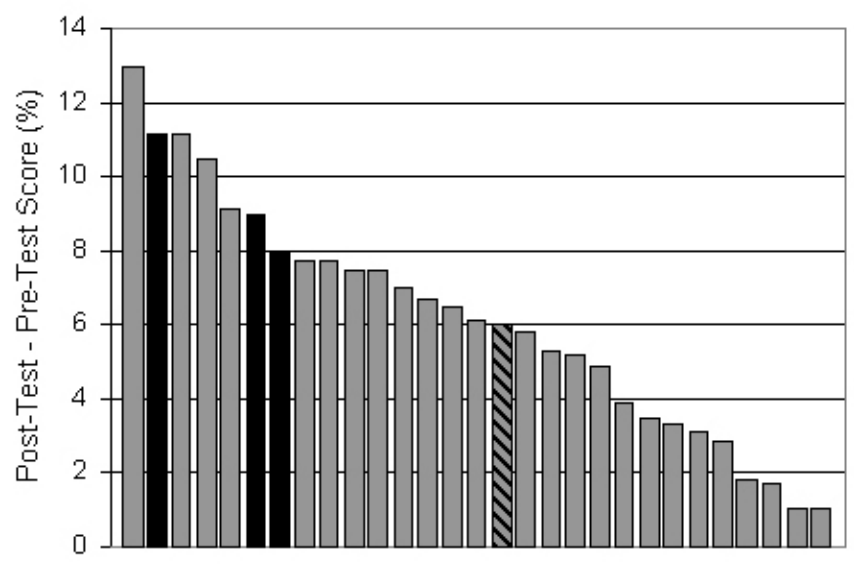

Figure 2. Comparison of difference among pre- and post-test in Geosciences Concepts Inventory (GCI) scores at three institutions from this study using conceptests (black bars) and 25 institutions (solid gray bars) where instructors utilized a variety of teaching methods. Diagonal pattern indicates control class taught without using conceptests at one of the three institutions piloting the use of conceptests. Classes taught using conceptests ranked in the upper third on GCI scoring. Note that GCI data from a fourth institution is not included because original scores were not available for analyses.

the beginning of each class to address misconceptions revealed in work completed for the previous class and to examine students' understanding of a critical concept to be examined in the current lab session. Students at Eastern Kentucky University were asked to write a brief explanation for their answer choices and these responses were used to identify alternative conceptions that presented a potential obstacle to student learning.

Student Learning - Instructors assessed student learning using instruments designed to measure understanding of geoscience concepts. Four instructors used a 20-question version of the Geosciences Concepts Inventory (GCI; Libarkin and Anderson, 2005) as a preand post-test assessment for their courses. The GCI is a valid and reliable measure of student understanding of critical geological concepts (Libarkin and Anderson, 2005). When given as a pre- and post-test in thirty different introductory geology courses at institutions across the United States, researchers found that only 13 of the courses showed a statistically significant improvement in student scores between the pre- and post-tests (Libarkin and Anderson, 2005). To put it another way, students in most of the introductory classes tested did not learn any new information related to the geological concepts tested on the GCI. As one of the instructors involved in this study noted after giving the GCI to his "control" class that did not incorporate conceptests:

... in the past I've gotten good teaching reviews and I've received good peer reviews as well. So, then I gave this (GCI) test and I found out that the students were not learning very much and so I said to myself, "Now I'm going to add these conceptests and (student scores) improved ... I can go to people and say "Look, I'm a good teacher by several measures and the students did not learn anything from me. And now since we did this (added conceptests) they interacted more, there was a lot more going on, a lot more engagement".

All four instructors who used conceptests and the GCI saw an improvement of student scores on the inventory from pre- to post-test. Student pre-test scores ranged from $41-48 \%$ and post-test scores varied from $49-58 \%$. The degree of improvement in student performance, as measured by the difference between pre- and post-test scores, was consistently higher than that reported from almost all other administrations of the test (Julie Libarkin, personal communication, 2004; Figure 2). Analysis of two sections of the same course taught by the same instructor without and with the use of conceptests during successive semesters at the same institution revealed that students in the conceptest class outperformed their peers on the GCI ( Figure 3). We note that there are many factors that could potentially impact student performance on the GCI. We simply offer that the use of conceptests is one potential mechanism to enhance student performance.

\section{ASSESSMENT}

What can the use of conceptests teach instructors about the role of assessment, the types of assessments, and the emphasis on assessment in course design and delivery? In their own words, faculty involved in this project reported:

I really didn't think that much about assessment [prior to coming to last summer's workshop]. Assessment was done by looking at student evaluations [of the course] - did they like the course - that was a factor in tenure decisions down the road. I look at it [assessment] entirely differently today.

I always ask [students] after the first exam - what could you do better - [a form of self assessment]. Those are all nice qualitative things, but I wanted to understand quantitatively -- are they learning, are they getting anything we're teaching them. . . . I think conceptests are more complicated than the rhetorical ones I was using. So, I'm getting some measure of their ability to read and answer questions during class time and that is very valuable.

If you used the conceptests before and after instruction you can see if there's any impact on students' learning... Three or four years ago I don't really think I thought [about the big picture], but now I think there's probably about 20 things [content] students should take away from class and how to think as well.

The use of conceptests can provide a mechanism to introduce quantitative formative assessment on learning in addition to the summative qualitative assessment of teaching represented by student evaluations. The increasing emphasis on program assessment in higher education may require that departments identify a common assessment strategy such as the use of conceptests to measure student learning of common concepts between different courses.

Student Satisfaction - Several instructors utilized electronic response systems to monitor student responses to conceptests while others used flash cards or had students raise their hands. Regardless of the method 


\section{Pre- \& Post-Test Improvement Difference}

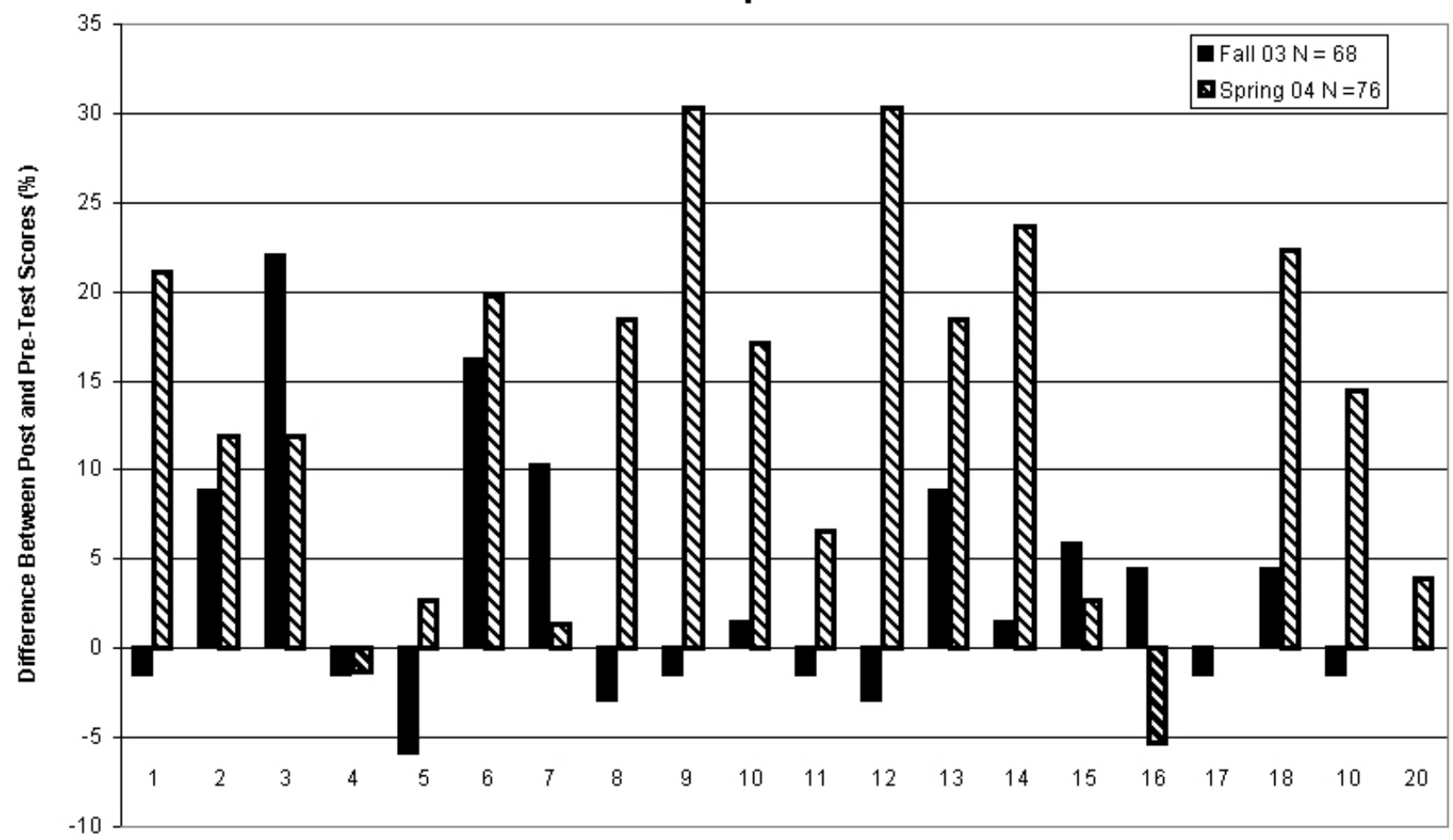

Question Number

Figure 3. Comparison of specific question scores from the 20-question Geosciences Concepts Inventory between two classes taught by the same instructor. The first class (Fall 03) was taught without using conceptests and peer instruction while the second class (Spring 04) incorporated conceptests and peer instruction (Spring 04). Both classes covered similar material. Negative differences indicate a lower percentage of correct responses on the post-test. Questions with zero difference have no bar. Greater gains (or a smaller reduction in score) are evident for the class using conceptests on 16 of the 20 questions.

used, a substantial majority of students had a favorable impression of the teaching method. Sample instructor comments included:

The overall reaction of the students to conceptests is one of excitement. Questions are taken seriously. Flash cards are handed out . . students pay close attention to the lecture in anticipation of when the conceptest question will pop-up.

The class fully participates in the exercise; I have seen no hesitation in students raising their hands . . Students carefully think about their answers and write decent rationales in defending their choices. Students often crave to know the answers . . they want to discuss the answer after the exercise. I sense more energy in the class.

Students perceived that the conceptests had a positive impact on their learning (Figure 4). More than $80 \%$ of students in courses taught by instructors who introduced conceptests in laboratory sections of an Introductory Geology course at Western Washington University found these methods useful in helping them learn (Figure 4). Analysis of student comments recorded as part of the class evaluation at Muskingum College revealed that a substantial majority of students $(89 \%)$ believed that the conceptests were beneficial. In general, students noted that conceptests gave them an opportunity to test their understanding of course material, let them discuss their answers with others, and added vitality and interest to the class (Wenk et al., 1997; McConnell et al., 2003; Greer and Heaney, 2004).

Student Attendance - No effort was made to collect daily data on student attendance, nor did most instructors have a record of attendance in past classes to compare, but instructor observations in all lecture classes suggest that attendance improved in those sections employing conceptests and peer instruction. Greer and Heaney (2004) report an increase in attendance rates in large lecture classes at Pennsylvania State University from $40-50 \%$ to $80-90 \%$ as a result of introducing the use of conceptests with an electronic personal response system. In some cases students earned points toward a grade as a result of their responses to conceptests (Greer and Heaney, 2004), but most instructors in this study did not award points when using the conceptests.

Overcoming Barriers to Change - Most instructors harbor misconceptions about how students learn based on their personal experiences (Nelson, 1996). Even when faculty might think they are promoting higher-order reasoning they may be actually teaching rote learning (Murray and MacDonald, 1997). Instructors commonly generate many apparently reasonable explanations as to why students perform better in other classes (e.g., older students, smaller classes, different class schedules). Consequently, instructors have difficulty making substantial changes to their established mental model of 
Conceptests: Useful vs. Not Useful

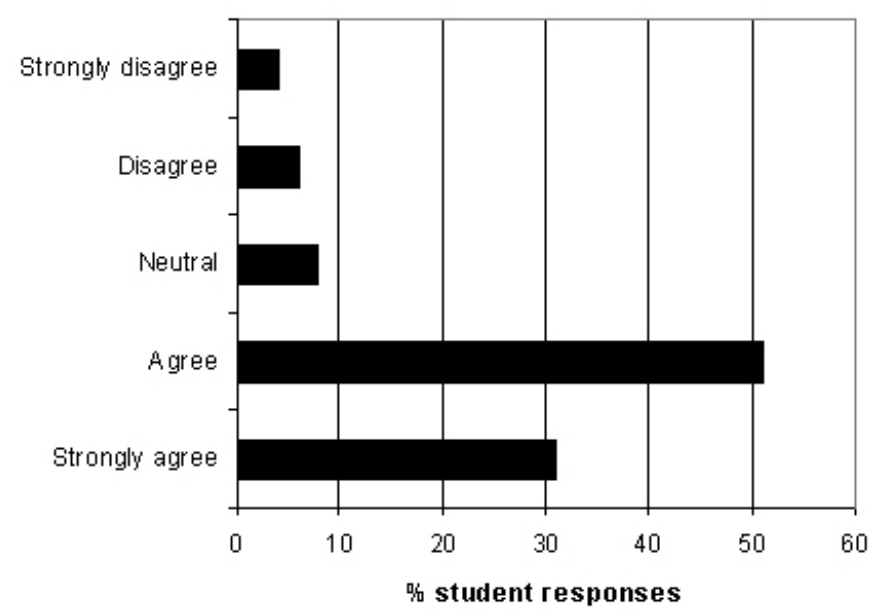

Figure 4. Student perceptions of the use of conceptests as a useful teaching and learning tool in an introductory geology laboratory course at Western Washington University. Proportion of students in three sections ( $n=72)$ who ranked the use of conceptests in their lab sections on a scale of 1-5 where $1=$ conceptests were not useful and $5=$ conceptests were useful.

student learning. A common observation among educators is that it is difficult to learn something that we don't almost already know (Angelo, 1993). Similarly, instructors struggle to incorporate a technique or teaching method into the class that is substantially dissimilar from methods they already utilize. For example, most instructors have few reservations about making changes to a course if those changes are tied to an existing product, such as new textbook editions. Likewise, the introduction of conceptests into a course may be more straightforward in classes where the questions can represent the natural evolution from existing quizzes or multiple-choice tests. Both instructors and students are familiar with such methods and the use of conceptests require only modest changes to class procedures.

Many of the instructors in this study were adding conceptests to their courses for the first time, yet found the introduction of this technique to be uncomplicated. When asked to describe the challenges of implementing conceptests these responses from different instructors were representative of the group as a whole:

It's been very easy; I did the very bare bones, lazy professor approach where I took the lectures I had and said, "Well, I'd like to insert a question", so I inserted a question. I went to the question bank and pulled one out and used those questions "as is". . . Often I'd change the question around for the exam.

Actually, it was quite easy. It took 10-15 minutes (of preparation time).

The easy part has been incorporating them in class. There's nothing easy in writing them, but there is something easy in using them.

Not only did the instructors find the integration of the questions to be straightforward, they also observed the positive impact of the use of the conceptests and peer instruction on their students. As one instructor noted:
I think it has tremendous impact. I could see that the students enjoyed interacting with one another; sometimes there were heated discussions going on; ... they were actually talking about what I wanted them to be talking about, and doing it enthusiastically. Their enthusiasm didn't wane over the course of the semester. They approached each and every conceptest in class with about the same enthusiasm, which I thought was great.

\section{CONCLUSIONS}

Increasing demands for enhancing student learning, greater instructor accountability for student learning and decreasing enrollment trends in many STEM programs necessitate careful examination of alternative strategies for teaching geoscience. Improving instructional methods is the least costly and most easily accomplished alternative. The combination of conceptests and peer instruction exhibits the characteristics of best practices for undergraduate education and has been a successfully and effectively implemented teaching technique in other science disciplines. Our data from several instructors who have used these questions in a range of courses at several different institutions show quantifiable gains in students' understanding, apparent improvements in attendance, greater student engagement, and heightened student satisfaction with their class experience.

Based on the instructor comments, we infer that the successful integration of conceptests and peer instruction was enhanced by the existence of a sufficiently large conceptest database. These conceptests are being disseminated through the Starting Point web site at Carleton College (http:/ / serc.carleton.edu/ introgeo/index.html). Several hundred conceptests are available at the site grouped by topic. Potential contributors may submit new questions and instructors can submit data on student responses to the existing questions.

\section{ACKNOWLEDGMENTS}

This material is based upon work supported by the National Science Foundation under Grant No. 0087894. We thank reviewers Marli Miller, Scott Rice-Snow, and James Myers for their thoughtful suggestions and Julie Libarkin and her colleagues for making a version of the Geoscience Conceptest Inventory available for our use. Finally, we are grateful for the work of the folks at the Starting Point Digital Library Collection, especially Cathy Manduca and John McDaris, who created a platform to disseminate and assess conceptests for the geoscience community.

\section{REFERENCES}

American Geophysical Union, 1994, Report of the AGU Chapman Conference on scrutiny of undergraduate geoscience education, 55p.

Angelo, T.A., 1993, A "Teacher's dozen", American Association of Higher Education Bulletin, April, p. 3-13.

Astin, A.W., and Astin, H.S., 1993, Undergraduate Science Education: The Impact of different college environments on the educational pipeline in the sciences, Higher Education Research Institute, Los Angeles.

Bykerk-Kauffman, A., 1995, Using cooperative learning in college geology classes, Journal of Geological Education, v.43, p. 309-316. 
Chickering, A.W., and Gamson, Z.F., 1987, Seven principles for good practice in undergraduate education, American Association of Higher Education Bulletin, March, p. 3-7.

Cox, A.J., and Junkin, W.F., III, 2002, Enhanced student learning in the introductory physics laboratory, Physics Education, v. 37, p. 37-44.

Crouch, C.H., and Mazur, E., 2001, Peer Instruction: Ten years of experience and results, American Journal of Physics, v. 69, p. 970-977.

Ebert-May, D., Brewer, C., and Allred, S., 1997, Innovation in large lectures - teaching for active learning, Bioscience, v.47, p. 601-607

Fleming, N., 1995, I'm different; not dumb: Modes of presentation (V.A.R.K.) in the tertiary classroom, in Zelmer, A., ed., Research and Development in Higher Education, Proceedings of the 1995 Annual Conference of the Higher Education and Research Development Society of Australasia (HERDSA), HERDSA, v.18, p. 308-313.

Gibbons, A., 1994, A time of trials and tribulations, Science, v.266, p. 844, 845, and 851.

Greer, L., and Heaney, P.J., 2004, Real-time analysis of student comprehension: An assessment of electronic student response technology in an introductory Earth Science course, Journal of Geoscience Education, v. 52, p. 345-351.

Hake, R.R., 1998, Interactive-engagement versus traditional methods: A six-thousand-student survey of mechanics test data for introductory physics courses, American Journal of Physics, v. 66, p. 64-74.

Handelsman, J., Ebert-May, D., Beichner, R., Bruns, P., Chang, A., DeHaan, R., Gentile, J., Lauffer, S., Stewart, J., Tilghman, S.M., and Wood, W.B., 2004, Scientific teaching, Science, v. 304, p. 521-522.

Jones, L.R., Miller, A.G., and Watts, J.F., 2001, Conceptual learning and quantitative problem solving: Friends or Foes?, Journal of Cooperation and Collaboration in College Teaching, v. 10, p. 109-116.

Judson, E., and Sawada, D., 2002, Learning from past and present: Electronic response systems in college lecture halls, Journal of Computers in Mathematics and Science Teachning, v. 21, p. 167-181.

Landis, C.R., Ellis, A.B., Lisensk, G.C., Lorenz, J.K., Meeker, K., and Wamser, C.C., 2001, Chemistry conceptests: A pathway to interactive classrooms: Prentice Hall, 99p.

Libarkin, J.C., and Anderson, S.W., 2005, Science concept inventory development in higher education: A mixed-methods approach in the geosciences, In press, Journal of College Science Teaching.

Kovac, J., 1999, Student active learning methods in general chemistry, Journal of Chemical Education, v. 76, p. 120-124.

Mazur, E., 1997, Peer instruction: A user's manual, Prentice Hall, 253 p.

Macdonald, R.H. and Korinek, L., 1995, Cooperative-learning activities in large entry-level geology courses, Journal of Geological Education, v. 43, p. 341-345.

McConnell, D.A., Steer, D.N., and Owens, K.D., 2003 Assessment and active learning strategies for introductory geology courses, Journal of Geoscience Education, v. 51, p. 205-216.

McConnell, D.A., Steer, D.N., Owens, K.D., and Knight, C., 2005, How students think: Implications for learning in introductory geoscience courses, Journal of Geoscience Education, v. 53, p. 462-470.

McManus, D.A., 2002, The two paradigms of education and the peer review of teaching, Journal of Geoscience Education, v.49, p. 423-434.

Meltzer, D.E., and Manivannan, K., 2002, Transforming the lecture-hall environment: The fully interactive physics lecture, American Journal of Physics, v.70, p.639-654.

Murck, B., 1999, Promoting and evaluating participation in high-enrollment undergraduate courses, Journal of Geoscience Education, v. 47, p. 131-134.

Murray, H., 1983, Low-inference classroom teaching behaviors and student ratings of college teaching effectiveness, Journal of Educational Psychology, v. 75, p. 138-149.

Murray, K. and R. MacDonald, 1997, The disjunction between lecturer's conceptions of teaching and their claimed educational practice, Higher Education, v. 33, p. 331-349.

National Research Council, 1997, Science teaching reconsidered, National Academy Press, 88 p.

National Science Foundation, 1996, Shaping the future: New expectations for undergraduate education in science, mathematics, engineering, and technology, $76 \mathrm{p}$.

National Science Board, 2002 Science and Engineering Indicators, National Science Foundation, Arlington, VA.

National Science Board, 2003, The science and engineering workforce: Realizing America's potential, National Science Foundation, Arlington, VA.

Nelson, C.E., 1996, Student diversity requires different approaches to college teaching, even in math and science, American Behavioral Scientist, v. 40, p. 165-175.

Piepmeier, E., Jr., 1998, Use of conceptests in a large lecture course to provide active student involvement and peer teaching, American Journal of Pharmaceutical Education, v. 62, p. 347-351.

Pilzer, S., 2001, Peer instruction in physics and mathematics, Primus, v. 11, p. 185-192.

Rao, S.P., and DiCarlo, S.E., 2000, Peer instruction improves performance on quizzes. Advances in Physiology Education, v. 24, p. 51-55.

Reynolds, S.J., and Peacock, S.M., 1998, Slide observations - Promoting active learning, landscape appreciation, and critical thinking in introductory geology courses, Journal of Geoscience Education, v.46, p. 421-426.

Seymour, E., and Hewitt, N.M., 1997, Talking about leaving: Why undergraduates leave the sciences, Westview Press, Boulder.

Sokoloff, D.R., and Thornton, R.K., 1997, Using interactive lecture demonstrations to create an active learning environment, The Physics Teacher, v.35, p. 340-347.

Sorcinelli, M.D., 1991, Research findings on the seven principles, New Directions for Teaching and Learning, \#47, p. 13-25.

Stokstad, E., 2003, Reintroducing the intro course, Science, v. 293, p. 1608-1610.

Strenta, A.C., Elliott, R., Adair, R., Matier, and Scott, J., 1994, Choosing and leaving science in highly selective institutions, Research in Higher Education, v. 35, \#5, p. 513-547.

Tobias, S., 1990, They're not dumb, they're different: Stalking the second tier, Research Corporation, $94 \mathrm{p}$.

Uno, G.E., 1997, Learning about learning through teaching about inquiry, in, Student Active Science: Models of Innovation in College Science Teachings, eds. A.P. McNeal and C. D'Avanzo, p. 189-198, Saunders College Publishing.

Wenk, L., Dufresne, R., Gerace, W., Leonard, W., and Mestre, J., 1997, Technology-assisted active learning in large lectures, in, Student Active Science: Models of Innovation in College Science Teachings, eds. A.P. McNeal and C. D'Av anzo, p. 431-451, Saunders College Publishing. 


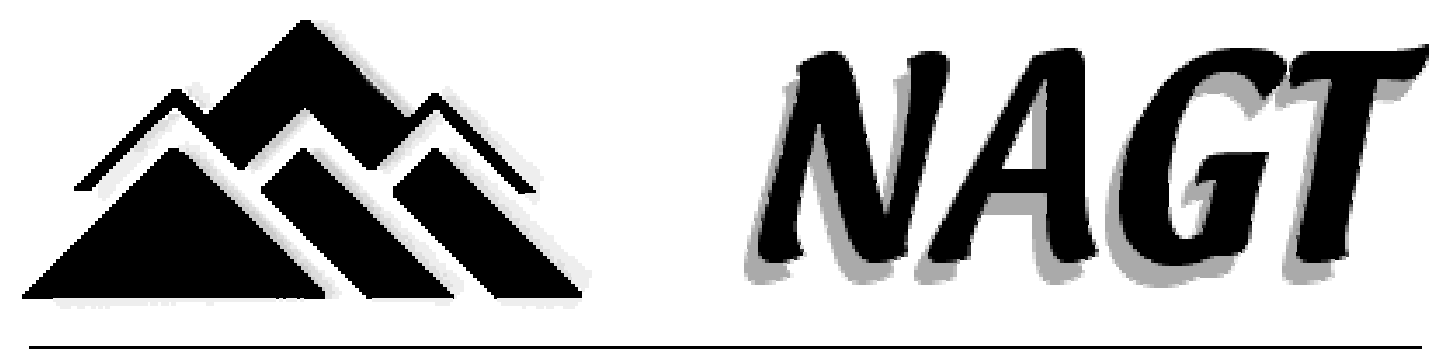

National Association of Geoscience Teachers

\section{Membership Application or Renewal Form}

Name:

Mailing Address:

City:

College/University Professor @

Precollege Teacher @

__other @

Checks, MasterCard, or VISA (US funds only) are payable to:National Association of Geoscience Teachers. Mail to: NAGT, PO Box 5443, Bellingham, WA 98227-5443
Phone:

Fax:

Email:

Zip:

\begin{tabular}{|ll|}
\hline Membership & Rates (US funds) \\
Regular USA & $\$ 35$ \\
Outside USA & $\$ 47-$ \\
Student-USA & $\$ 20-$ \\
Student-outside USA & $\$ 32 \square$ \\
Retired NAGT member & $\$ 30$ \\
Library Subscriptions & \\
Regular USA & $\$ 55$ \\
Outside USA & $\$ 67 \_$ \\
New &
\end{tabular}

a Check

a Credit card: MC/VISA (circle one) Number:

Signature: Exp. Date

The Journal and membership year runs from January to December. Subscriptions received after June 1 will begin receiving the Journal in January of the following year. Back issues are available for $\$ 15$ (foreign $\$ 18$ ) each.

*To qualify for student rate, indicate and obtain verification from a NAGT member: 